\title{
Levers of Control and Managerial Performance: The Importance of Belief Systems
}

\author{
Ancella Anitawati Hermawan*a, Emil Bachtiar ${ }^{\star}$, Panggah Tri Wicaksono ${ }^{a}$, Nia Pramita Sart \\ ${ }^{a}$ Universitas Indonesia, Indonesia
}

\begin{abstract}
Belief systems, which are one of the four levers of control, play a vital role in an organization. This study is primarily aimed at examining the effects of belief systems on managerial performance. Since the four levers of control jointly function in management control systems, we extend our study by investigating whether the contingent-fit between strategic risk, strategic uncertainty, and the other three levers of control (i.e., boundary systems, diagnostic control, and interactive control) strengthens the association between belief systems and managerial performance. A survey questionnaire was distributed to the upper-level management of various companies or strategic business units in Indonesia during the fourth quarter of 2017, resulting in 81 respondents. Hypotheses testing were conducted using the OLS regression model. This research found that belief systems are positively associated with managerial performance, indicating that the implementation of effective belief systems leads to higher managerial performance. This study also found that the contingent-fit between strategic risk, strategic uncertainty, and the other three levers of control does not have any effect on how belief systems are positively associated with managerial performance. This finding indicates that although management does not adopt a fit combination between its level of strategic risk and strategic uncertainty and the boundary systems, diagnostic control, and interactive control, it can still achieve good performance as long as strong belief systems are implemented. These findings confirm the critical role of belief systems in the levers of control. Thus, management needs to ensure the establishment of more effective belief systems if the company or business unit wants to produce optimal performance.
\end{abstract}

Keywords: belief systems, levers of control, managerial performance, strategic risk, strategic uncertainty.

JEL Classification: M140, M410 


\section{Introduction}

The massive development of the business world brings about strategic uncertainty and strategic risks for a company. Management control system (MCS) is a management tool used for ensuring the implementation of the strategy set in the context of achieving the company's goals. In facing challenges, an effective MCS can help the company achieve the targeted performance. Simons (1995, 2000) developed a management control concept known as the levers of control (LOC) consisting of belief systems (i.e., the basic values of a company), boundary systems (i.e., setting boundaries on actions and behavior), diagnostic control (e.g., monitoring), and interactive control (e.g., involving subordinates in the evaluation of the company). According to Simons (1995), a company must apply the four levers in the right combination to effectively execute a strategy. It is suggested that the four levers jointly function in control, and each is complementary (Widener, 2007).

As one of the four levers of control, belief systems play a critical role in an organization. Belief systems provide the core values of an organization (Simons, 1995), and are used by the top management to inspire and motivate employees to give their best efforts to supporting the organization (Widener, 2007). The mission statement, vision, corporate credo, and values can be used to articulate a company's belief systems. Thus, compared to the other three levers of control, we argue that belief systems are a very effective MCS because it is the self-control that comes from within the individual. Unlike other control systems, belief systems cannot be measured easily with respect to performance and cannot be associated with rewards and punishment. Moreover, belief systems provide directions for decision making, even though a company faces conditions of great uncertainty. In coping with unpredictable circumstances, belief systems are often used to provide signals to the employees about the organization's strategic objectives, so that they can adjust their actions to the expected outcomes (Speklé, 2001). Heinicke et al., (2016) found that companies that implement a flexible culture will emphasize the use of belief systems.

Despite the importance of belief systems in an organization, the effects of belief systems on a company's performance remain underexplored in the literature. One of the few studies was conducted by Sai Manohar and Pandit (2014), who investigated the role of the core values and beliefs of leading innovative companies in India. The findings of Sai Manohar and Pandit's (2014) study suggest that the innovation culture of these companies was heavily influenced by their core values and beliefs. Meanwhile, Bart et al., (2001) and Sidhu (2003) found that the mission statement of a company positively affects the company's performance. As the effects of belief systems on a company's performance have only received little attention so far, this study wants to enrich the literature by providing further empirical evidence. Thus, the primary aim of this study is to examine the impacts of belief systems on managerial performance. The main research question is as follows: "How do belief systems affect managerial performance?"

Due to the vital role of belief systems, we argue that establishing effective belief systems should become a company's priority. Furthermore, it has been suggested by prior studies that the LOC are an interdependent system (Marginson, 2002; Chenhall et al., 2010; Frow et al., 2010; Mundy, 2010). Bedford (2015) examined the impact of each lever 
of control individually, and in a complementary manner, on a company's performance for different modes of innovation, and tested the impact of equilibrium in the four levers of control. Bedford's (2015) findings suggest that the individual levers of control have better performing associations, and in ambidextrous firms, diagnostic control and interactive control have an interdependent impact on performance. Moreover, Widener (2007) found that the implementation of boundary systems and interactive control complement the belief systems. Widener's (2007) findings also suggest that companies that emphasize belief systems will highlight the other three levers of control. Thus, it is expected that the interdependence of the other three levers of control (i.e., boundary systems, diagnostic control, and interactive control) can also strengthen the role of belief systems.

The LOC concept states that the strategic uncertainties and strategic risks facing a company are the antecedents to determining the priority when choosing control systems, which ultimately have an impact on the control's effectiveness (Simons, 1995). Strategic risks can be defined as unforeseen events or situations that may adversely affect a manager's ability to carry out a strategy. Meanwhile, strategic uncertainties are uncertainties and contingencies that may threaten or weaken a company's strategy. Since companies face different levels of strategic risks and uncertainties, each company should adopt an optimal combination of the LOC depending on the levels of the strategic risks and uncertainties that the company faces. This corresponds with the assumptions underlying the contingency theory, that there is no single type of organizational structure that can be applied to all organizations. Organizational effectiveness depends on the fit or alignment between contingent factors (Islam and Hu, 2012).
As belief systems play a crucial role, they should ideally be prioritized regardless of the levels of strategic risks and strategic uncertainties that a company faces. However, the company should also adopt the other three control systems because the four levers jointly function in control (Widener, 2007). Therefore, in the context of this study, the fit can be achieved by aligning the other three levers of control (i.e., boundary systems, diagnostic control, and interactive control) with the strategic risks and uncertainties. It is expected that this fit can strengthen the role of belief systems in a company. Thus, in addition to the aforementioned primary research question, we would like to extend our study to investigate whether the contingent-fit between strategic risk, strategic uncertainty, and the other three levers of control can enhance the role of belief systems in achieving the targeted managerial performance. The research question is as follows: "How does the contingent-fit between strategic risk, strategic uncertainty, and the other three levers of control (i.e., boundary systems, diagnostic control, and interactive control) affect the association between belief systems and managerial performance?"

Previous studies have examined the contingent-fit between diagnostic control, interactive control, and business strategy (Abernethy and Brownell, 1999; Bedford, 2015; Bisbe and Otley, 2004; Henri, 2006; Miller and Friesen, 1982). In addition, MCS research related to the contingency theory focuses extensively on how the type of control system becomes a contextual factor with respect to strategy choice. Jermias and Gani (2005) used the contingent-fit between competitive strategy choices and contextual factors, namely the degree of centralization, types of control, and types of management accounting systems. With the appropriate 
combination and harmony with the chosen strategy, the contingent-fit will positively affect the performance of a company's business unit. Since there are limited studies that explore the contingent-fit between strategic risk, strategic uncertainty, and the other three levers of control as additional control systems to the belief systems in implementing business strategy, we expect this research to develop and complete the literature on MCS.

\section{Literature Review}

\section{Levers of Control (LOC)}

The LOC are a framework, developed by Simons (1995), to implement and control business strategy. The four critical issues associated with this framework are the core corporate values, risks to be avoided, essential variables of performance, and strategic uncertainties. Each of these critical issues is controlled by a particular system that is part of the LOC. The company's core values are controlled by the belief systems that guide the creative process to explore new opportunities and establish shared values (Simons, 1995). The risks to be avoided are controlled by the boundary systems' negative role, providing constraints on opportunities sought by the company (Simons, 1995). Key performance variables are controlled by diagnostic controls that monitor, assess, and appreciate achievements in key performance areas. Meanwhile, strategic uncertainty is controlled through interactive control, which contribute to developing new ideas and strategies. Simons (1995) suggests that to implement a strategy successfully, a company must apply the four levers in an appropriate combination. It is also suggested that the LOC is an interdependent system (Marginson, 2002; Chenhall et al., 2010; Frow et al., 2010; Mun- dy, 2010), where the four levers jointly function in control, and each is complementary (Widener, 2007).

The LOC are recognized to have some strengths, but are also criticized for some weaknesses. Ferreira (2002) found that this framework focuses strongly on strategic issues and their implications for control systems. The LOC also offer a broader perspective on control systems through the scope of the controls applied and how they are used in a company. The specific use of certain control mechanisms makes for a better understanding of the design of MCS. Importantly, this LOC framework provides typologies for the use of other MCS recognized in the literature as meaningful and useful (Abernethy and Lillis, 2001; Bisbe and Otley, 2004; Henri, 2006; Bisbe et al., 2007; Widener, 2007). This aspect is essential because the way these control systems are used is critical in determining whether the four levers of control are suitably applied and assessing the balance between positive and negative controls (Ferreira, 2002).

Ferreira (2002) also identifies some weaknesses of the LOC. The LOC are highly focused on top management and do not pay much attention to some forms of informal control in organizations, especially small firms (Ferreira, 2002), or control over lower hierarchy levels. Therefore, this framework does not adequately explain the implementation of an overall control system, especially when informal control plays an important role. Another disadvantage is that the concepts inherent in the LOC, such as the core values of the firm, have various meanings that can lead to subjective interpretations (Ferreira, 2002). In addition, there is also ambiguity in the definition of interactive control. This framework also has problems that are not 
universally applicable. In some organizations, such as branches or subsidiaries, belief systems and boundary systems are mostly not in the control domain of the branches or subsidiaries.

Research into the LOC also reveals some weaknesses of the LOC. Bisbe and Otley (2004) examined the relationship between interactive control and innovation, and found that the relationship depends on the company's level of innovation. In companies with high levels of innovation, the interactive control has a negative effect on innovation. However, in companies with low levels of innovation, the interactive control has a positive effect. Henri (2006) determines that the use of diagnostic control negatively affects the strategic capabilities, such as market orientation, entrepreneurship, innovation ability, and organizational learning, while the interactive control has a positive effect.

Collier (2005) examines the interplay between belief systems and boundary systems in entrepreneurial-oriented organizations, while other research has used the LOC framework to interpret case-study evidence related to the issue of MCS (Ferreira, 2002; Tuomela, 2005). Another critical study was done by Widener (2007), which found that the linkage and complementarity between the four levers of control and performance measurements are more useful for diagnostic control and interactive control. He also supports Simons' $(1995,2000)$ argument that managers should consider the four control systems mentioned above when designing their control systems, to improve the effectiveness reflected in organizational performance.

\section{Belief Systems}

Belief systems are a set of organizational-identity statements communicated formally by the executives and systematically echoed to provide the organization's core values, including its organizational values, goals, and direction. Belief systems also include how the organizational values are created, the level of desired performance, and human relationships (Simons, 1995). Belief systems can be expressed in a mission and vision statement, credo, statement of purpose, and values. Executives use belief systems to inspire and motivate employees to seek, explore, create, and put all their efforts into engaging in actions that support the organization (Widener, 2007). Simons (1995) emphasizes the important role of managers in an organization to establish effective belief systems. Senior managers can personally write substantive drafts and form a staff group to facilitate communication, feedback, and awareness among all members. Since belief systems are the self-control that come from within an individual, they are effective management control systems, and that their role in an organization is vital. Thus, an organization should ideally prioritize establishing effective belief systems.

Belief systems will create a stable environment for members of the organization and play an essential role in overcoming, through the communication of values and assumptions, organizational indifference to the organizational inertia and political processes that occur in the organization. Belief systems convey the goals and values that are not routinely reflected in the MCS. Thus, belief systems serve as the basis for the criteria used in decision making and they create the operational paradigms in which the other systems within the LOC operate (Dent, 1991 cited in Mundy, 2010). Furthermore, even when an organization faces high levels of uncertainty, belief systems provide direction for the organization's decision-making. Belief systems 
are used when dealing with uncertain situations to provide signals about organizational strategic goals to the organization's members so that they can adapt their behavior to the expected outcomes (Speklé, 2001).

To the authors' best knowledge, there is no research that specifically examines the impact of belief systems on a company's or business unit's performance. However, there is one study discussing the core values and beliefs found in the most innovative companies (Sai Manohar and Pandit, 2014). Sai Manohar and Pandit (2014) used a survey of 50 executives from 15 of the most innovative companies in India and identified some common ground in these companies, namely that core values and beliefs play an important role in the companies. Some other studies focus more on the mission statement, which includes the mission and vision of the organization. Initial research on mission statements (Baetz and Bart, 1996; Bart, 1997; Bart and Tabone, 1999) has focused more on examining the completeness of mission statements with respect to the use of and satisfaction with the mission statement, including satisfaction in the preparation of mission statements.

Bartkus et al., (2004) compared the quality of mission statements of Japanese and US companies, based on the following criteria: identifying stakeholders, incorporating specific components, and fulfilling the functions of the mission statement (i.e., directing communication, helping to control, guiding decision-making, and motivating employees). Bartkus et al., (2004) observed that, although there are differences between the companies from both countries, the mission statement's quality was still under the criteria they used. In this article, they did not examine whether a low-quality mission statement had an impact on the company's performance. However, in another article, they found that low quality did not affect performance (Bartkus et al., 2006).

Bart et al., (2001) tried to develop a model that traces the link between the mission and the company's performance. The variables they use are the reasons to create a mission, mission content, job satisfaction, alignment between the mission and organizational content, employee behavior, commitment, and performance. Using a sample of 83 companies and questionnaires that they believe are long, they observe a positive relationship between the mission and company's performance. Meanwhile, Sidhu (2003) explains that there is a positive relationship between mission comprehensiveness and firm's performance. Sidhu (2003) completed content analysis on missions and measured mission comprehensiveness based on the presence of the elements of vision, competence, and values. Meanwhile, a company's performance is measured by the respondents' perception of their company's sales growth performance compared to its nearest competitor. Sidhu (2003) concludes that the mission statement has a positive effect on a company's performance.

\section{Strategic Risk, Strategic Uncertainty, and Levers of Control}

In a business context, a strategy can be defined as how an organization can achieve its business objectives by competing with other organizations (Emblemsvåg and Kjølstad, 2002). In executing its strategy, an organization faces strategic risks and strategic uncertainties. A strategic risk is an unexpected event or condition that can significantly affect a manager's capability to implement 
a strategy. Meanwhile, strategic uncertainties are uncertainties and contingencies that can threaten or weaken a company's strategy. Strategic uncertainties arise from senior managers' perceptions of known or unknown contingencies, which can threaten and undo the assumptions used to build the company's strategy. Although the risk and uncertainty terms are used interchangeably in general, some experts define uncertainty as the inability to establish the probability of outcomes, whereas risk is defined as the ability to establish probabilities based on differences in perception of regular relationships or patterns (Emblemsvåg and Kjølstad, 2002; Gifford et al.,1979).

Strategic risks and strategic uncertainties are two of four critical issues associated with the framework of the levers of control (LOC). Boundary systems are designed to communicate risks that must be avoided and eliminate any ability that can rationalize actions that could bring undesirable risks to the company (Simons, 2000). Meanwhile, interactive control is a control system that motivates searches and learning and is used when top management has a perception of there being a high level of strategic uncertainties. With interactive control, management is encouraged to intensify the search for new strategies to respond to opportunities and threats (Simons, 1995).

According to the LOC concept, strategic risks and strategic uncertainties are the antecedents to determining the priorities when a company selects a control system ( $\mathrm{Si}$ mons, 1995). Companies face different levels of strategic risks and strategic uncertainties. Therefore, each company should adopt an appropriate combination of the LOC that aligns with the levels of strategic risks and strategic uncertainties that the company fac- es. Lababidi et al., (2020) also state that, in reality, companies create strategies in various ways depending on the context, in order to produce effective strategies. McAdam et al., (2019) also suggest that if a company faces a more dynamic and complex business environment, the strategy tends to be more complex or advanced to adapt to the context. These arguments are related to the assumption underlying the contingency theory that there is no single type of organizational structure that can be applied to the entire organization.

The contingency theory is an approach to organizational behavior studies in which contingent factors, such as technology, culture, and the external environment, affect the organization's design and function. An organization's effectiveness depends on the fit between the contingent factors (Islam and $\mathrm{Hu}, 2012)$. Lababidi et al., (2020) argue that achieving the fit or alignment between strategic planning and the contextual factors of organizational structure and environmental uncertainty leads to the generation of good performance. Drazin and Van de Ven (1985) explain that fit can be defined using two approaches, namely contingent, and congruence, in the study of accounting and strategic management. The relationship of two or more variables forming a fit is conditional in the contingent approach. Conversely, the relationship of two or more variables that form a fit does not have to be conditional in the congruence approach, but the relationship already exists by itself. In this study, fit refers to a contingent approach.

It was explained previously that belief systems play a critical role, and that a company should prioritize establishing effective belief systems regardless of the levels of strategic risks and strategic uncertainties that 
a company faces. Besides, a company should also adopt the other three levers of control (i.e., boundary systems, diagnostic control, and interactive control). Due to the interdependency of the four levers, it is expected that the interdependence of the other three control systems can also enhance the function of belief systems. Widener (2007) suggests that companies that emphasize belief systems will highlight the other three levers of control. Following the contingency theory, the fit can be achieved by aligning the following contingent factors: the other three control systems (i.e., boundary systems, diagnostic control, and interactive control), strategic risks, and strategic uncertainties. Achieving this fit is expected to strengthen the role of the belief systems in the company.

\section{Hypothesis Development}

Compared to the other three levers of control, belief systems are a very effective MCS because they are the self-control within an individual. Belief systems provide directions for decision making, even though the company is in a condition of high uncertainty. Heinicke et al., (2016) found that a flexible organizational culture has a positive relationship with the implementation of belief systems in a company. Despite the importance of belief systems, studies that examine the effects of belief systems on performance are still limited. Sai Manohar and Pandit (2014) suggest that the culture of innovation in India's leading innovative companies is heavily influenced by the companies' core values and beliefs. Meanwhile, Bart et al., (2001) and Sidhu (2003) found that the mission statement of a company, which is an articulation of the company's belief systems, positively affects the company's performance. Therefore, the central hypothesis of this study is as follows:
$H_{1}$ : The implementation of belief systems is positively associated with managerial performance.

In addition to the central argument that belief systems are positively associated with managerial performance, this study also examines how the contingent fit between strategic risk, strategic uncertainty, and the other three levers of control (i.e., boundary systems, diagnostic control, and interactive control) affects the association between belief systems and managerial performance. Management control system (MCS) is not an isolated system, but a system that interacts with its external environment (Malmi and Brown, 2008), such as the strategic risks and uncertainties. Simons (2000) suggests that the effectiveness of the implementation of MCS cannot be seen from the application of a single lever of control alone, but from its interaction with the other levers of control. Following the contingency theory, a company should ideally achieve a fit or alignment between the other three levers of control (i.e., boundary systems, diagnostic control, and interactive control), strategic risks and strategic uncertainties, in order to ensure the effectiveness of its MCS. When facing strategic risks and uncertainties, MCS that is effectively implemented can help the company or business unit to achieve its targeted performance, and further enhance the role of belief systems in achieving performance. Therefore, the second hypothesis of this study is as follows:

$H_{2}$ : The positive association between belief systems and managerial performance is more profound in companies with a bigher contingent-fit between strategic risks, strategic uncertainties, and the other three levers of control.

Based on the development of these hypotheses, the conceptual framework of this study is illustrated in Figure 1. 


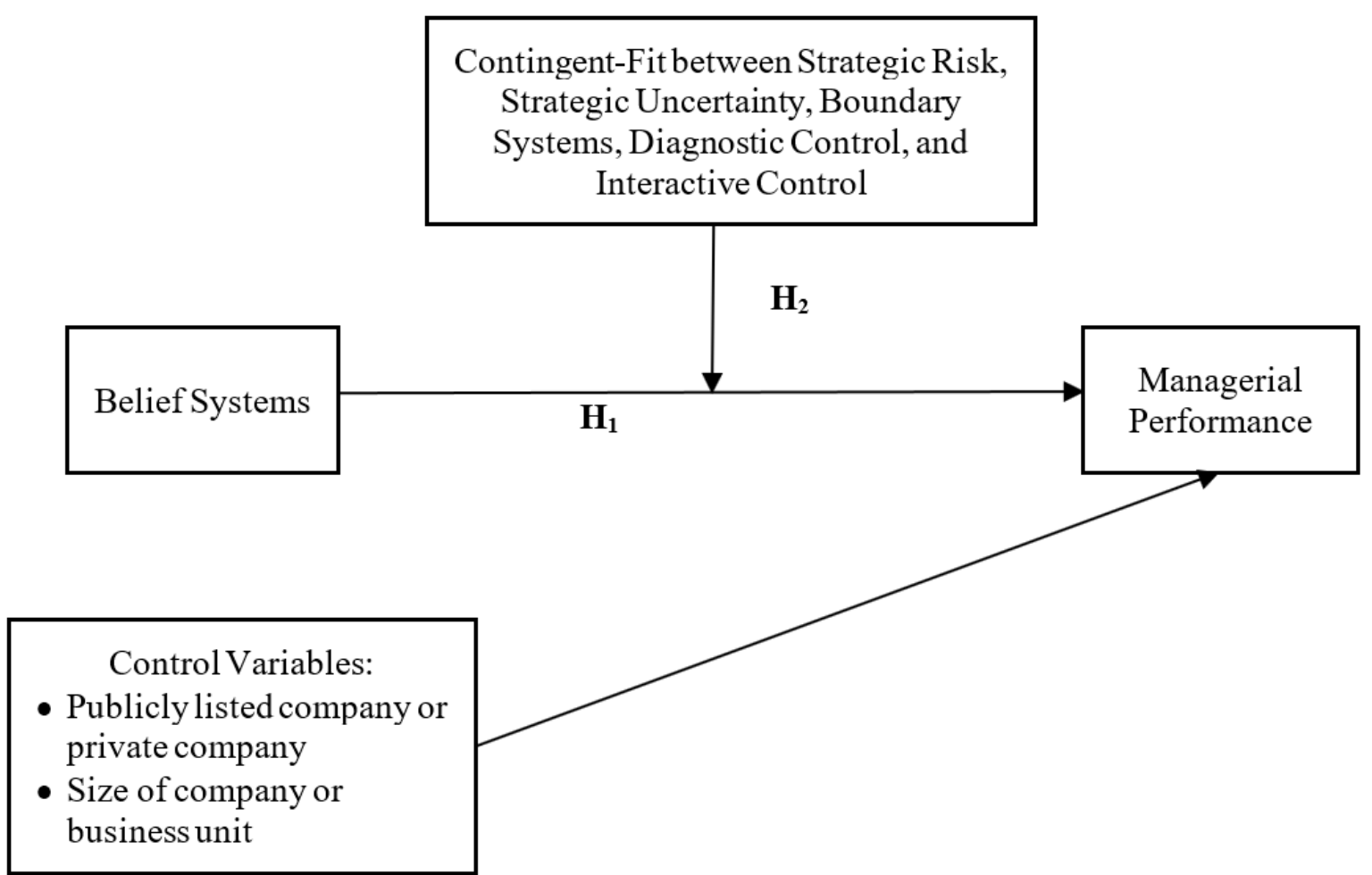

Figure 1. Conceptual Framework

\section{Methods}

\section{Sampling Technique and Data Collec- tion}

This study was an empirical study using quantitative data analysis. This study used primary data obtained through a survey in the form of a questionnaire. The survey questionnaire was aimed at collecting participants' perceptions about the control systems, strategic risks and uncertainties, and the performance of their organization. Appendix A to this paper presents the questions included in the questionnaire. Therefore, the target respondents were members of the upper-level management of companies or profit centers' strategic business units. The companies where the respondents are employed are located in Indonesia and can be either a private company or a publicly-listed company on the Indonesia Stock Exchange (IDX).
Figure 2 illustrates the research method workflow. We developed the questions in the questionnaire by adopting them from Bedford (2015) and Widener (2007), notably those related with performance and belief systems applied by a company or business unit within a company. Several steps were taken before distributing the survey questionnaire to the potential respondents. Firstly, we asked five faculty members, who also hold upper-level managerial positions in their company, to check whether all the questions could be understood by the potential respondents. Feedback from the faculty members was followed up by clarifying some of the questions in the questionnaire. Secondly, we distributed 30 questionnaires after finalizing the instrument based on the feedback. Lastly, we performed reliability and validity tests on these $30 \mathrm{com}$ pleted questionnaires and concluded that the instrument (the survey questionnaire) was reliable and valid. Thus, the data collected from 
Gadjah Mada International Journal of Business - September-December, Vol. 23, No. 3, 2021

these 30 completed questionnaires were then included in the data analysis. to the respondents, such as: the researchers ensure the participants' data confidentiality,

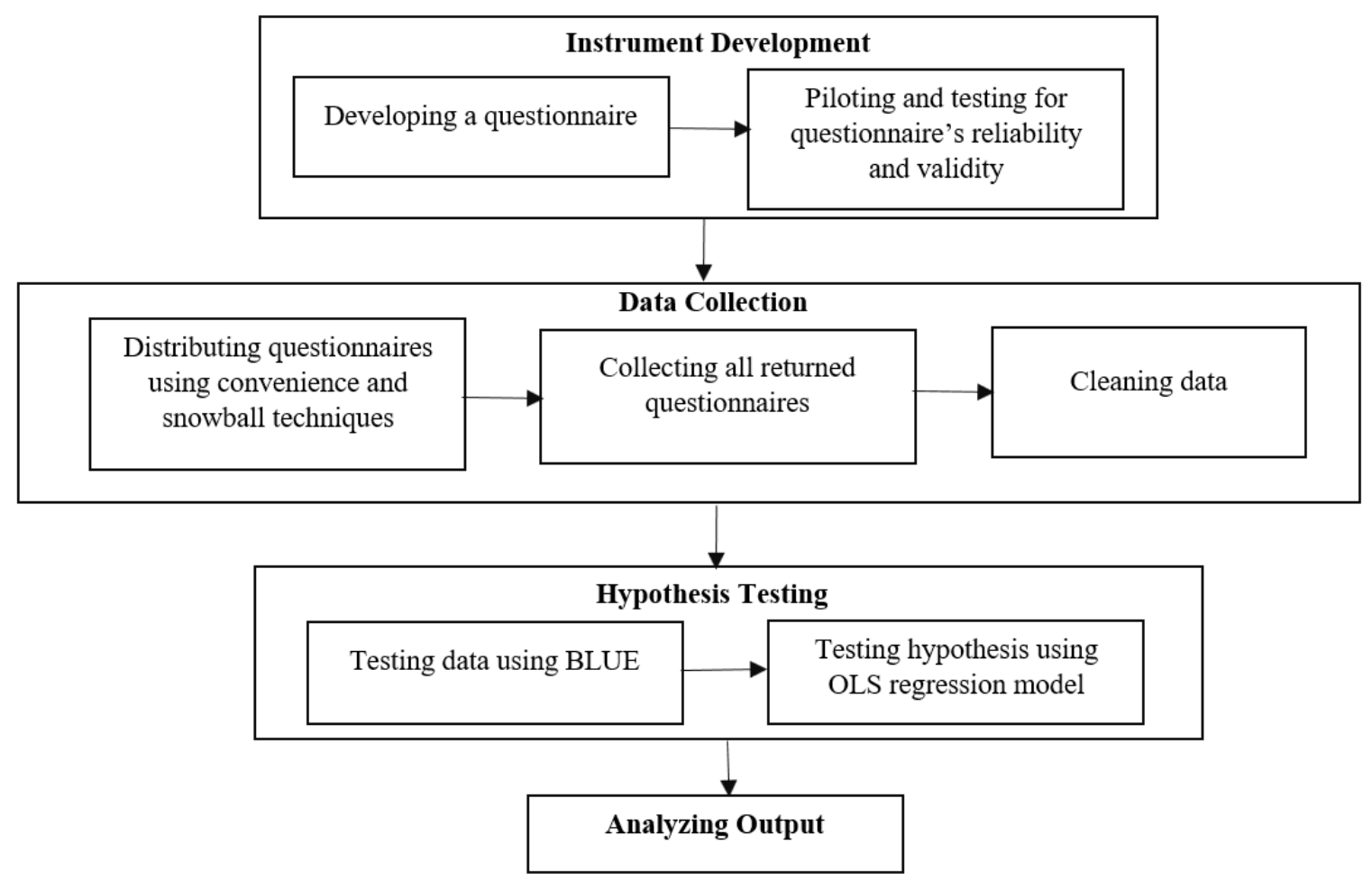

Figure 2. Research Method Workflow

We obtained 81 respondents from distributing the survey questionnaires during the fourth quarter of 2017. As suggested by Heckathorn (2011), we employed non-probability sampling methods, convenience and snowball sampling methods to access hardto-reach populations to hopefully get them to participate in this study. Also, we distributed the questionnaires to students in the master's professional program to ensure a sufficient response rate. In order to ensure the students met our criteria (i.e., being a part of upper-level management at their company or business unit within a company), we asked 14 questions regarding the characteristics of the organizations they work in, each participant's profile, and their role in the organization. Before the participants filled out the survey questionnaires, we provided explanations and that their participation in this research is voluntary and they can withdraw without any unfavorable consequences. In order to control the time period, all the steps in the sampling and data collection processes were carried out from October until December 2017. After all the processes for collecting the data were completed, we cleaned our data to boost the data's validity.

\section{Measurement}

The model used to test the hypotheses consisted of Equation 1 (for $\mathrm{H}_{1}$ ) and Equation $2\left(\right.$ for $\left.\mathrm{H}_{2}\right)$, where PERF = company performance; BLF = belief systems applied by the company or business unit; FIT = contingent-fit between strategic risk, strategic uncertainty, and the contextual variables (i.e., 
boundary systems, diagnostic control, and interactive control); BLF*FIT = interaction between the variables belief systems (BLF) and contingent-fit (FIT); PUBLIC = company is listed on the Indonesia Stock Exchange or not; and SIZE = company's or business unit's size.

$\mathrm{PERF}=\alpha+\beta_{1} \mathrm{BLF}+\beta_{2} \mathrm{PUBLIC}+\beta_{3} \mathrm{SIZE}$ $+\varepsilon \quad(1)$

$\mathrm{PERF}=\alpha+\beta_{1} \mathrm{BLF}+\beta_{2} \mathrm{FIT}+\beta_{3} \mathrm{BLF} * \mathrm{FIT}+$ $\beta_{4}$ PUBLIC $+\beta_{5} \mathrm{SIZE}+\varepsilon$

The dependent variable (PERF) and the independent variable (BLF) were represented by a set of questions adopted from Bedford (2015) and Widener (2007). The level of strategic risk, level of strategic uncertainty, and contextual variables (i.e., boundary systems, diagnostic control, and interactive control) were also measured using the questions in the questionnaire. Each of the questions was measured using a Likert scale ranging from 1 to 5 . ing different levels of strategic uncertainty and strategic risk. Fit is developed using the following assumptions: (1) Companies facing a high level of strategic risk and a high level of strategic uncertainty should place more emphasis on the use of boundary systems and interactive control and less emphasis on the use of diagnostic control. (2) Companies facing a high level of strategic risk and a low level of strategic uncertainty should not emphasize the use of interactive control, but should emphasize the use of boundary systems and diagnostic control. (3) Companies facing a low level of strategic risk and a high level of strategic uncertainty should emphasize the use of interactive control, but should not emphasize the use of boundary systems and diagnostic control. (4) Companies facing a low level of strategic risk and a low level of strategic uncertainty should not emphasize the use of interactive control and boundary systems, but should emphasize the use of diagnostic control. These assumptions are also shown in Table 1.

Table 1. Combination Matrix for Strategic Risk, Strategic Uncertainty, and the Three Levers of Control (LOC)

\begin{tabular}{ccccc}
\hline Strategic Risk & $\begin{array}{c}\text { Strategic Uncer- } \\
\text { tainty }\end{array}$ & Boundary Systems & Diagnostic Control & Interactive Control \\
\hline High & High & High & Low & High \\
High & Low & High & High & Low \\
Low & High & Low & Low & High \\
Low & Low & Low & High & Low \\
\hline
\end{tabular}

The FIT variable was measured from three contextual variables: boundary systems, diagnostic control, and interactive control. The contingent-fit was developed based on the fitness-landscape theory, which describes the level of fit between the level of strategic risk, the level of strategic uncertainty, and the three contextual variables (i.e., boundary systems, diagnostic control, and interactive control). It was used to show how the three LOC were combined in the companies fac-
To determine the contingent-fit, the sample was divided into four categories of strategic risk and uncertainty conditions, i.e., high risk and high uncertainty, high risk and low uncertainty, low risk and high uncertainty, and low risk and low uncertainty. The contingent-fit scores for each sample were calculated using the FIT calculation adopted from the formula used by Jermias and Gani (2005). The formula determines the average number of responses to the questionnaire related to 
the contextual variables (i.e., boundary systems, diagnostic control, and interactive control). The fit calculation model is as follows, where Fit . $_{\mathrm{i}}$ total score of contingent-fit for sample $\mathrm{j} ; \mathrm{X}_{\mathrm{ij}}=$ contribution of fit from contextual variables $\mathrm{i}$ for sample $\mathrm{j} ; \mathrm{N}=$ number of contextual variable; $j=$ number of sample.

$$
\text { Fit }_{j}=\frac{1}{N} \sum_{i=1}^{N} X_{i j}, \forall_{j}=1 \ldots j
$$

To ensure that the high FIT scores illustrate the best alignment between strategic risk, strategic uncertainty and the contextual variables, this study used a reverse code for the contextual variables with a "low" level, as shown in Table 1. For example, in high risk and high uncertainty conditions, diagnostic control tends to be low, so for the sample category of high strategic risk and high uncertainty, a reverse code is performed for the respondent's response in the contextual variable of diagnostic control. Therefore, the questionnaire questions on the diagnostic control use a value of one to indicate a low level of interactive control and a value of five to indicates a high level of interactive control.

This study uses two control variables: the company's ownership (PUBLIC) and the company's or business unit's size (SIZE). The company's ownership (PUBLIC) is a dummy variable with the value of one if the company is listed on the Indonesia Stock Exchange (IDX) and zero if otherwise. The company's or business unit's size (SIZE) is measured based on its total assets (excluding land and buildings) or annual sales value, whichever is higher. The value of this variable is 1 for micro size, 2 for small size, 3 for medium size, and 4 for large size. The criterion for each category is provided in the questionnaire in Appendix A.

\section{Data Analysis}

The research model was tested based on the ordinary least squares (OLS) method using Stata software. Before that, classical assumptions were tested to ensure the data are processed using a best linear unbiased estimator (BLUE), in the form of normality, heteroscedasticity, and multicollinearity tests. A Pearson correlation test was also performed to test the relationships between each independent variable. Analyses of the data were conducted based on the descriptive statistics, the correlation test results, and the OLS test results. Descriptive statistics explained the respondents' profiles and the tested variables.

\section{Results}

\section{Descriptive Statistics}

A total of 81 respondents were obtained from the questionnaires distributed for this

Table 2. Profile of Respondents

\begin{tabular}{lll}
\hline Characteristics & $\mathbf{N}$ & $\%$ \\
\hline Gender: & 54 & \\
Male & 27 & $66.7 \%$ \\
Female & & $33.3 \%$ \\
\hline Age & 44 & \\
$23-32$ years old & 22 & $54.3 \%$ \\
$33-42$ years old & 10 & $27.2 \%$ \\
$43-52$ years old & 5 & $12.3 \%$ \\
$>52$ years old & & $6.2 \%$ \\
\hline
\end{tabular}


Hermawan et al

\begin{tabular}{|c|c|c|}
\hline Characteristics & $\mathbf{N}$ & $\%$ \\
\hline \multicolumn{3}{|l|}{ Latest Education } \\
\hline Diploma 3 & 1 & $1.2 \%$ \\
\hline Undergraduate & 68 & $84.0 \%$ \\
\hline Postgraduate (Master) & 10 & $12.3 \%$ \\
\hline Postgraduate (Doctoral) & 2 & $2.5 \%$ \\
\hline \multicolumn{3}{|l|}{ Number of Subordinates } \\
\hline$<10$ subordinates & 54 & $66.7 \%$ \\
\hline 10-50 subordinates & 21 & $25.9 \%$ \\
\hline 50-100 subordinates & 4 & $4.9 \%$ \\
\hline$>100$ subordinates & 2 & $2.5 \%$ \\
\hline \multicolumn{3}{|l|}{ Member of Top Management } \\
\hline Yes & 21 & $25.9 \%$ \\
\hline No & 60 & $74.1 \%$ \\
\hline \multicolumn{3}{|l|}{ Type of Company } \\
\hline Subsidiary company & 6 & $7.4 \%$ \\
\hline Profit-center business unit - branch & 3 & $3.7 \%$ \\
\hline Profit-center business unit - division & 12 & $14.8 \%$ \\
\hline Company & 60 & $74.1 \%$ \\
\hline \multicolumn{3}{|l|}{ Size of Company } \\
\hline Micro & 1 & $1.2 \%$ \\
\hline Small & 3 & $3.7 \%$ \\
\hline Medium & 14 & $17.3 \%$ \\
\hline Large & 63 & $77.8 \%$ \\
\hline \multicolumn{3}{|l|}{ Public Company (Listed on IDX) } \\
\hline Yes & 45 & $55.6 \%$ \\
\hline No & 36 & $44.4 \%$ \\
\hline
\end{tabular}

Table 3. Descriptive Statistics of Variables

\begin{tabular}{llllll}
\hline Variable & Mean & $\begin{array}{l}\text { Standard Devi- } \\
\text { ation }\end{array}$ & Min & Max & Skewness \\
\hline PERF & 3.9599 & 0.8501 & 1.0000 & 5.0000 & -1.3109 \\
BLF & 3.0559 & 0.3535 & 2.2167 & 3.6667 & -0.2494 \\
FIT & 3.1327 & 1.0659 & 1.0000 & 5.0000 & 0.0995 \\
SIZE & 3.7160 & 0.5965 & 1.0000 & 4.0000 & -2.3044 \\
\hline
\end{tabular}

study. Table 2 shows that most respondents are male, in the age group of 23 to 32 years old, have an undergraduate degree, have fewer than 10 subordinates, and are not members of the top management. Most of the respondents are working in large companies or business units, and the proportion of public companies is just slightly higher than that of private companies. These sample characteristics should give a comprehensive representation of the research findings.
Table 3 illustrates that the average value for each of the PERF and BLF is more than the mean of the respective Likert scale values, which indicates that the business unit or the company has a high level of performance and the level of application of the belief systems is also high. The standard deviation value for both variables reveals that the sample diversity is not very high, in terms of performance and the level of application of belief systems. In addition, the average 
contingent-fit value is 3.1327 (which is more than the mean of the possible values for the contingent-fit), indicating that the business unit or the company also has a high degree of alignment between strategic risk, strategic uncertainty and the other three levers of control applied by the company (i.e., boundary systems, diagnostic control, and interactive control). The standard deviation value indicates that the contingent-fit values are also not very diverse.

\section{Results and Analysis}

Based on the results presented in Table 4 , it can be seen that belief systems are positively associated with the performance of companies or business units. This result denotes that the implementation of stronger belief systems will produce better performance, so Hypothesis 1 is confirmed. Nevertheless, the contingent-fit between strategic risk, strategic uncertainty, and the combination of the other three levers of control used (i.e., boundary systems, diagnostic con- trol and interactive control) in companies or business units does not significantly affect the positive association between belief systems and the performance of companies or business units, therefore Hypothesis 2 is not confirmed.

The findings of this research also indicate that publicly listed companies have lower managerial performance than non-publicly listed companies. In addition, the results also show that as the company or business unit gets larger in size, the managerial performance decreases. The findings of these control variables confirm that achieving higher managerial performance in bigger companies or business units, and in public companies, is more challenging. This may indicate that an effective management control system is more critical for public companies, and bigger companies or business units, to achieve high performance. Therefore, management should have a better understanding about the implementation of the levers of control to produce an optimal control system.

Table 4. Results of Hypothesis Testing

\begin{tabular}{|c|c|c|c|c|c|}
\hline \multirow{2}{*}{$\begin{array}{c}\text { Dependent Var: } \\
\text { PERF }\end{array}$} & \multirow{2}{*}{ Expected Sign } & \multicolumn{2}{|c|}{$\mathrm{H}_{1}$} & \multicolumn{2}{|c|}{$\mathbf{H}_{2}$} \\
\hline & & Coefficient & Prob. & Coefficient & Prob. \\
\hline BLF & + & 0.443 & $0.001 * * *$ & -0.193 & 0.402 \\
\hline FIT & + & & & -1.039 & 0.155 \\
\hline BLF*FIT & + & & & 0.221 & 0.216 \\
\hline PUBLIC & $+/-$ & -0.309 & $0.028^{* *}$ & -0.318 & $0.023 * *$ \\
\hline SIZE & $+/-$ & -0.442 & $0.036^{* *}$ & -0.459 & $0.032 * *$ \\
\hline \multicolumn{2}{|c|}{ Adjusted R-Squared } & \multicolumn{2}{|c|}{0.1492} & \multicolumn{2}{|c|}{0.1342} \\
\hline \multicolumn{2}{|c|}{ Prob $>$ chi $^{2}$} & \multicolumn{2}{|c|}{0.0002} & \multicolumn{2}{|c|}{0.0009} \\
\hline
\end{tabular}

*** significant with confidence level $\alpha=1 \%$ (one-tailed)

** significant with confidence level $\alpha=5 \%$ (one-tailed)

Observations: 81 respondents; PERF = the level of the company's or business unit's financial and overall performance; BLF = belief systems implemented by the company or business unit; FIT = contingent-fit between strategic risk, strategic uncertainty, and boundary systems, diagnostic control, and interactive control; PUBLIC $=$ dummy variable with a value of one if the company is publicly listed at IDX, and zero if otherwise; SIZE = company's or business unit's size. 


\section{Discussion and Findings}

This study aimed to investigate the role of belief systems as the main pillar of the levers of control in enhancing a company's or a business unit's managerial performance. In addition, this study also strives to explore whether the contingent-fit between strategic risk, strategic uncertainty, and the other three levers of control can enhance the role of belief systems in achieving the targeted managerial performance. Therefore, we formulated two hypotheses and the findings have been presented in the preceding section.

Testing the first hypothesis confirms a positive association between belief systems and managerial performance. This result indicates that companies or business units that implement stronger belief systems would have better managerial performance. Belief systems are explicit sets of beliefs that define the basic values, purpose and direction, including how value is created, the level of desired performance, and human relationships (Simons, 1995). Belief systems provide guidance for opportunity-seeking behavior, especially when opportunities expand dramatically or there is a change of strategic direction. Senior managers should define and communicate their company's set of beliefs to all the employees, so that everyone in the organization would share the same perspectives and values in any decision situation. This finding supports the previous studies, which found that maintaining belief systems will help management in its decision-making, especially in uncertain situations. Speklé (2001) suggests that in uncertain circumstances, an organization can use belief systems to provide its members with signals about its organizational strategic goals so that the members can adapt their actions to the expected outcomes. This finding also corresponds with Bart et al.,
(2001) and Sidhu (2003), who confirm that the company's mission statement influences performance, where the company's mission statement is one of the depictions of the belief systems.

There are three practical implications that can be drawn from this finding. Firstly, the need for a company to have formal documentation of its organizational core values in the form of vision and mission statements, credos, and a statement of purpose. An organization's core values provide guidance to its employees, where rules and standard operating procedures alone cannot suffice. Management should communicate this set of beliefs effectively to all the organization's members to ensure their decisions and actions reflect the organization's core values. Secondly, the organization's core values should originate from the founder's core values and be clearly defined and stated by the management. If the founders do not have any core values, it would be difficult for the organization to have effective belief systems, unless the management has a very strong leadership. Therefore, companies or business units should have a leader with profound leadership skills, in order to have strong belief systems. Lastly, the tone from the top and leadership by example are the key success factors to have strong belief systems in a company or a business unit. Managers ought to actively communicate and internalize the core values to their subordinates, thus creating a strong commitment from all the elements in a company or a business unit. For instance, managers can lead their subordinates by providing examples of how to perform day-to-day activities in accordance with the company's or the business unit's core values.

The result of our second hypothesis shows that the contingent-fit between strategic risk, strategic uncertainty, and the com- 
bination of priority control systems implemented in business units or companies (i.e., boundary systems, diagnostic control, and interactive control) does not significantly affect the association between belief systems and managerial performance. This finding denotes that although a company or a business unit is not able to operate the other three levers of control (i.e., boundary systems, diagnostic control, and interactive control) in an ideal manner, in accordance with the level of strategic risk and uncertainty they are facing (as presented in Table 1) to achieve the desired fit or alignment, the company or business unit can still achieve a good performance as long as they implement strong belief systems. This finding is important to note, particularly when a company or a business unit operates in rapidly changing situations (e.g, in the time of a pandemic or crisis).

The findings indicate that the role of belief systems in the levers of control is critical to achieving the targeted managerial performance. This study contributes to the body of knowledge by proving that given the strategic risk and strategic uncertainty faced by a company or a business unit, belief systems are the most essential form of control among the four levers of control. Therefore, a company or a business unit should prioritize the establishment of more effective belief systems so that these can help to achieve better performance. The belief systems solely become an important control in the management control system, regardless of whether the company or business unit has an appropriate contingent-fit between strategic risks, strategic uncertainties, and the other three levers of control. However, the other three control systems (i.e., boundary systems, diagnostic control, and interactive control) should not be ignored, because the LOC are an interdependent system (Marginson, 2002; Chenhall et al., 2010; Frow et al., 2010; Mundy, 2010). Widener (2007) also suggests that companies that emphasize belief systems also highlight the other three levers of control.

In addition to the main results, we examined the association of the contingent-fit of strategic risks, strategic uncertainties, and boundary systems, diagnostic control, and interactive control, with managerial performance (not presented in this article). The result shows that there is no association between the contingent-fit of those factors and managerial performance. This result supports our previous findings that belief systems are the critical lever of control, especially when the company or business unit is facing strategic risks and strategic uncertainties. Management do not have to worry about finding which of the levers of control are best suited to face such risks and uncertainties to achieve the targeted performance, as long as they have built strong belief systems in the company or business unit. Management should just ensure that the company already has the belief systems, and the implementation of the boundary systems, diagnostic control, and interactive control could be based on the organization's needs.

\section{Conclusion}

This primary aim of this study was to investigate the effects of belief systems on managerial performance. Moreover, it has been noted that the four levers of control jointly function in the management control system. Therefore, this study also examines how the other three levers of control (i.e., boundary systems, diagnostic control, and interactive control), that are aligned with the levels of strategic risks and strategic uncertainties, can affect the association between belief systems and managerial performance. 
This study's findings complete the literature in terms of the significant impact of belief systems on managerial performance. The implication is that the establishment of belief systems in a company or a business unit is crucial for delivering satisfactory performance. With this, managements need to exert themselves in ensuring that effective belief systems are in place. The absence of any impact by the contingent-fit between strategic risk, strategic uncertainty, and the other three levers of control on the aforementioned relationship makes the belief systems even more crucial for achieving the desired managerial performance.

\section{Limitation}

We acknowledge that this study has several limitations, so we provide suggestions for future research. Firstly, the number of respondents in the sample obtained was not large, which may interfere with the results. Future research can increase the number of respondents in the sample. Furthermore, additional respondents can be taken from other countries in order to make comparisons between countries. Belief systems are closely related to culture, so it would be interesting to compare cultures in different countries in a new study. Secondly, the distribution of companies or business units represented by the respondents is not even. To better ensure that respondents represent business units or companies in equal numbers, it is necessary to determine the number of respondents for each business unit or company. Thirdly, the distribution of the industries of the respondents' companies or business units is also unequal. The levels of risk and uncertainty faced by firms in different industries may be different. Therefore, for a generalization, it is necessary to ensure that the samples represent each industry, so they can be compared. Fourthly, this research did not separate between business units and companies, where the authority of a business unit may be different from that of a company. Future studies can focus on top management only, or on business-unit managers alone, to obtain more homogeneous results. Lastly, we also acknowledge that this study cannot prove the hypothesis that the contingent-fit affects the association between belief systems and managerial performance. Thus, future research may need to try other fit measurements to find whether it can provide different results.

\section{Acknowledgment}

This research was funded by the 2017 Excellence Higher Education Institution Research (PUPT) Grant. We would like to acknowledge the Directorate General of Higher Education, Ministry of Research, Technology and Higher Education, Republic of Indonesia for providing the funding. 
Gadjah Mada International Journal of Business - September-December, Vol. 23, No. 3, 2021

\section{References}

Abernethy, M. A., \& Brownell, P. (1999). The role of budgets in organizations facing strategic change: An exploratory study. Accounting, Organizations and Society, 24(3), 189-204. https://doi.org/10.1016/S0361-3682(98)00059-2

Abernethy, M. A., \& Lillis, A. M. (2001). Interdependencies in organization design: A test in hospitals. Journal of Management Accounting Research, 13(1), 107-129. https://doi.org/10.2308/ jmar.2001.13.1.107

Baetz, M. C., \& Bart, C. K. (1996). Developing mission statements which work. Long Range Planning, 29(4), 526-533. https://doi.org/10.1016/0024-6301(96)00044-1

Bart, C. K. (1997). Industrial firms and the power of mission. Industrial Marketing Management, 26(4), 371-383. https://doi.org/10.1016/S0019-8501(96)00146-0

Bart, C. K., Bontis, N., \& Taggar, S. (2001). A model of the impact of mission statements on firm performance. Management Decision, 39(1), 19-35. https://doi.org/10.1108/ EUM0000000005404

Bart, C. K., \& Tabone, J. C. (1999). Mission statement content and hospital performance in the Canadian not-for-profit health care sector. Health Care Management Review, 24(3), 18-29. https://doi.org/10.1097/00004010-199907000-00003

Bartkus, B., Glassman, M., \& McAfee, R. B. (2004). A comparison of the quality of European, Japanese and U.S. mission statements: A content analysis. European Management Journal, 22(4), 393-401. https://doi.org/10.1016/j.emj.2004.06.013

Bartkus, B., Glassman, M., \& McAfee, R. B. (2006). Mission statement quality and financial performance. European Management Journal, 24(1), 86-94. https://doi.org/10.1016/j. emj.2005.12.010

Bedford, D. S. (2015). Management control systems across different modes of innovation: Implications for firm performance. Management Accounting Research, 28, 12-30. https://doi. org/10.1016/j.mar.2015.04.003

Bisbe, J., Batista-Foguet, J. M., \& Chenhall, R. (2007). Defining management accounting constructs: A methodological note on the risks of conceptual misspecification. Accounting, Organizations and Society, 32(7-8), 789-820. https://doi.org/10.1016/j.aos.2006.09.010

Bisbe, J., \& Otley, D. (2004). The effects of the interactive use of management control systems on product innovation. Accounting, Organizations and Society, 29(8), 709-737. https://doi. org/10.1016/j.aos.2003.10.010

Chenhall, R. H., Hall, M., \& Smith, D. (2010). Social capital and management control systems: A study of a non-government organization. Accounting, Organizations and Society, 35(8), 737-756. https://doi.org/10.1016/j.aos.2010.09.006

Collier, P. M. (2005). Entrepreneurial control and the construction of a relevant accounting. Management Accounting Research, 16(3), 321-339. https://doi.org/10.1016/j.mar.2005.06.007

Drazin, R., \& Van de Ven, A. H. (1985). Alternative forms of fit in contingency theory. Administrative Science Quarterly, 30(4), 514-539. https://doi.org/10.2307/2392695

Emblemsvåg, J., \& Endre Kjølstad, L. (2002). Strategic risk analysis: A field version. Management Decision, 40(9), 842-852. https://doi.org/10.1108/00251740210441063

Ferreira, A. M. F. (2002). Management accounting and control systems design and use: An exploratory study 
in Portugal. PhD. Lancaster University.

Frow, N., Marginson, D., \& Ogden, S. (2010). "Continuous” budgeting: Reconciling budget flexibility with budgetary control. Accounting, Organizations and Society, 35(4), 444-461. https:// doi.org/10.1016/j.aos.2009.10.003

Gifford, W. E., Bobbitt, H. R., \& Slocum, J. W. (1979). Message characteristics and perceptions of uncertainty by organizational decision makers. Academy of Management Journal, 22(3), 458-481. https://doi.org/10.5465/255738

Heckathorn, D. D. (2011). Comment: Snowball versus respondent-driven sampling. Sociological Methodology, 41(1), 355-366.

Heinicke, A., Guenther, T. W., \& Widener, S. K. (2016). An examination of the relationship between the extent of a flexible culture and the levers of control system: The key role of beliefs control. Management Accounting Research, 33, 25-41. https://doi.org/10.1016/j. mar.2016.03.005

Henri, J. F. (2006). Management control systems and strategy: A resource-based perspective. Accounting, Organizations and Society, 31(6), 529-558. https://doi.org/10.1016/j. aos.2005.07.001

Islam, J., \& Hu, H. (2012). A review of literature on contingency theory in managerial accounting. African Journal of Business Management, 6(15), 5159-5164. https://doi.org/10.5897/ ajbm11.2764

Jermias, J., \& Gani, L. (2005). Ownership structure, contingent-fit, and business-unit performance: A research model and empirical evidence. The International Journal of Accounting, 40(1), 65-85. https://doi.org/10.1016/j.intacc.2005.01.004

Lababidi, H. C., Lababidi, R., Colak, M., \& Dayan, M. (2020). Contingency effects of firm structure and environmental uncertainty on strategic planning process and firm performance: Evidence from UAE enterprises. Strategic Change, 29(2), 241-252.

Malmi, T., \& Brown, D. A. (2008). Management control systems as a package: Opportunities, challenges and research directions. Management Accounting Research, 19(4), 287-300. https://doi.org/10.1016/j.mar.2008.09.003

Marginson, D. E. W. (2002). Management control systems and their effects on strategy formation at middle-management levels: Evidence from a U.K. organization. Strategic Management Journal, 23(11), 1019-1031. https://doi.org/10.1002/smj.271

McAdam, R., Miller, K., \& McSorley, C. (2019). Towards a contingency theory perspective of quality management in enabling strategic alignment. International Journal of Production Economics, 207, 195-209.

Miller, D., \& Friesen, P. H. (1982). Innovation in conservative and entrepreneurial firms: Two models of strategic momentum. Strategic Management Journal, 3(1), 1-25. https://doi. org/10.1002/smj.4250030102

Mundy, J. (2010). Creating dynamic tensions through a balanced use of management control systems. Accounting, Organizations and Society, 35(5), 499-523. https://doi.org/10.1016/j. aos.2009.10.005

Sai Manohar, S., \& Pandit, S. R. (2014). Core values and beliefs: A study of leading innovative organizations. Journal of Business Ethics, 125(4), 667-680. https://doi.org/10.1007/ s10551-013-1926-5 
Gadjah Mada International Journal of Business - September-December, Vol. 23, No. 3, 2021

Sidhu, J. (2003). Mission statements: Is it time to shelve them? European Management Journal, 21(4), 439-446. https://doi.org/10.1016/S0263-2373(03)00072-0

Simons, R. (1995). Levers of control: How managers use innovative control systems to drive strategic renewal. Harvard Business School Press.

Simons, R. (2000). Performance measurement \& control systems for implementing strategy: Text \& cases. Prentice Hall.

Speklé, R. F. (2001). Explaining management control structure variety: A transaction cost economics perspective. Accounting, Organizations and Society, 26(4-5), 419-441. https://doi. org/10.1016/S0361-3682(00)00041-6

Tuomela, T. S. (2005). The interplay of different levers of control: A case study of introducing a new performance measurement system. Management Accounting Research, 16(3), 293-320. https://doi.org/10.1016/j.mar.2005.06.003

Widener, S. K. (2007). An empirical analysis of the levers of control framework. Accounting, Organizations and Society, 32(7-8), 757-788. https://doi.org/10.1016/j.aos.2007.01.001 


\section{APPENDIX A. Survey Questionnaire}

\section{SURVEY QUESTIONS SECTION A}

Please rate the extent to which the following statements described your company or profit center SBU in the last three years:

$1=$ very low extent $(\mathrm{VL})$

$2=$ low extent $(\mathrm{L})$

$3=$ moderate extent $(\mathrm{M})$

$4=$ high extent $(\mathrm{H})$

$5=$ very high extent $(\mathrm{VH})$

\begin{tabular}{|c|l|c|c|c|c|c|}
\hline No. & \multicolumn{1}{|c|}{ Statements } & VL & L & M & H & VH \\
\hline & Belief Systems & & & & & \\
\hline 1 & $\begin{array}{l}\text { The values, purpose and direction of the organiza- } \\
\text { tion are codified in formal documents (e.g. mission/ } \\
\text { value statements, credos, statements of purpose) }\end{array}$ & 1 & 2 & 3 & 4 & 5 \\
\hline 2 & $\begin{array}{l}\text { Top management actively communicates core values } \\
\text { to subordinates. }\end{array}$ & 1 & 2 & 3 & 4 & 5 \\
\hline 3 & $\begin{array}{l}\text { Formal statements of values are used to create com- } \\
\text { mitment to the long-term vision of top management. }\end{array}$ & 1 & 2 & 3 & 4 & 5 \\
\hline 4 & $\begin{array}{l}\text { Formal statements of values are used to motivate and } \\
\text { guide subordinates in searching for new opportuni- } \\
\text { ties. }\end{array}$ & 1 & 2 & 3 & 4 & 5 \\
\hline 1 & $\begin{array}{l}\text { Boundary Systems } \\
\text { Codes of conduct or similar statements are relied } \\
\text { upon to define appropriate behavior. }\end{array}$ & 1 & 2 & 3 & 4 & 5 \\
\hline 2 & $\begin{array}{l}\text { There are policies or guidelines that stipulate specif- } \\
\text { ic areas for, or limits on, opportunity searches and } \\
\text { experimentation. }\end{array}$ & 1 & 2 & 3 & 4 & 5 \\
\hline 3 & $\begin{array}{l}\text { As part of the top management, I actively commu- } \\
\text { nicate the risks and activities to be avoided by my } \\
\text { subordinates. }\end{array}$ & 1 & 2 & 3 & 4 & 5 \\
\hline 4 & $\begin{array}{l}\text { Sanctions or punishments are applied to subordinates } \\
\text { who engage in risks and activities outside organiza- } \\
\text { tional policy, irrespective of the outcome. }\end{array}$ & 1 & 2 & 3 & 4 & 5 \\
\hline
\end{tabular}


Gadjah Mada International Journal of Business - September-December, Vol. 23, No. 3, 2021

\begin{tabular}{|c|c|c|c|c|c|c|}
\hline No. & Statements & VL & $\mathbf{L}$ & $\mathbf{M}$ & $\mathbf{H}$ & VH \\
\hline & Diagnostic Control & & & & & \\
\hline 1 & $\begin{array}{l}\text { As part of the top management team, I use budgets } \\
\text { and performance measures to identify critical perfor- } \\
\text { mance variables (i.e. factors that indicate the achieve- } \\
\text { ment of the current strategy). }\end{array}$ & 1 & 2 & 3 & 4 & 5 \\
\hline 2 & $\begin{array}{l}\text { As part of the top management team, I use budgets } \\
\text { and performance measures to set targets for critical } \\
\text { performance variables. }\end{array}$ & 1 & 2 & 3 & 4 & 5 \\
\hline 3 & $\begin{array}{l}\text { As part of the top management team, I use budgets } \\
\text { and performance measures to monitor the progress } \\
\text { toward critical performance targets. }\end{array}$ & 1 & 2 & 3 & 4 & 5 \\
\hline 4 & $\begin{array}{l}\text { As part of the top management team, I use budgets } \\
\text { and performance measures to provide information to } \\
\text { correct deviations from preset performance targets. }\end{array}$ & 1 & 2 & 3 & 4 & 5 \\
\hline 5 & $\begin{array}{l}\text { As part of the top management team, I use budgets } \\
\text { and performance measures to review key areas of } \\
\text { performance. }\end{array}$ & 1 & 2 & 3 & 4 & 5 \\
\hline & Interactive Control & & & & & \\
\hline 1 & $\begin{array}{l}\text { As part of the top management team, I use budgets } \\
\text { and performance measures to provide a recurring and } \\
\text { frequent agenda for top management activities. }\end{array}$ & 1 & 2 & 3 & 4 & 5 \\
\hline 2 & $\begin{array}{l}\text { As part of the top management team, I use budgets } \\
\text { and performance measures to provide a recurring and } \\
\text { frequent agenda for my subordinates' activities. }\end{array}$ & 1 & 2 & 3 & 4 & 5 \\
\hline 3 & $\begin{array}{l}\text { As part of the top management team, I use bud- } \\
\text { gets and performance measures to enable continual } \\
\text { challenges to and debate about the underlying data, } \\
\text { assumptions and action plans with subordinates and } \\
\text { peers. }\end{array}$ & 1 & 2 & 3 & 4 & 5 \\
\hline 4 & $\begin{array}{l}\text { As part of the top management team, I use budgets } \\
\text { and performance measures to focus attention on } \\
\text { strategic uncertainties (i.e. factors that may invalidate } \\
\text { the current strategy or provide opportunities for new } \\
\text { strategic initiatives). }\end{array}$ & 1 & 2 & 3 & 4 & 5 \\
\hline 5 & $\begin{array}{l}\text { As part of the top management team, I use budgets } \\
\text { and performance measures to encourage and facil- } \\
\text { itate dialog and information sharing with subordi- } \\
\text { nates. }\end{array}$ & 1 & 2 & 3 & 4 & 5 \\
\hline
\end{tabular}




\section{SURVEY QUESTIONS SECTION B}

Please rate to the extent to which of the following statements described your firm or profit center SBU in the last three years:

$1=$ strongly disagree $(\mathrm{SD})$

$2=$ disagree $(\mathrm{D})$

$3=\operatorname{neutral}(\mathrm{N})$

$4=\operatorname{agree}(\mathrm{A})$

$5=$ strongly agree $(\mathrm{SA})$

\begin{tabular}{|c|l|c|c|c|c|c|}
\hline No. & \multicolumn{1}{|c|}{ Statements } & SD & D & N & A & SA \\
\hline & Strategic Uncertainties & & & & & \\
\hline & $\begin{array}{l}\text { As part of the top management team in our firm } \\
\text { (SBU), I monitor changes in product technology } \\
\text { that affect the relative cost/efficiency to the user, in } \\
\text { order to ensure that the goals of the firm (SBU) are } \\
\text { achieved. }\end{array}$ & 1 & 2 & 3 & 4 & 5 \\
\hline 2 & $\begin{array}{l}\text { As part of the top management in our firm (SBU), I } \\
\text { monitor new technology in order to ensure that the } \\
\text { goals of the firm (SBU) are achieved. }\end{array}$ & 1 & 2 & 3 & 4 & 5 \\
\hline 3 & $\begin{array}{l}\text { As part of the top management in our firm (SBU), I } \\
\text { monitor product introductions in adjacent industries } \\
\text { in order to ensure that the goals of the firm (SBU) } \\
\text { are achieved. }\end{array}$ & 1 & 2 & 3 & 4 & 5 \\
\hline 4 & $\begin{array}{l}\text { As part of the top management in our firm (SBU), I } \\
\text { monitor the market tactics of competitors in order to } \\
\text { ensure that the goals of the firm (SBU) are achieved. }\end{array}$ & 1 & 2 & 3 & 4 & 5 \\
\hline 5 & $\begin{array}{l}\text { As part of the top management in our firm (SBU), I } \\
\text { monitor new industry entrants in order to ensure that } \\
\text { the goals of the firm (SBU) are achieved. }\end{array}$ & 1 & 2 & 3 & 4 & 5 \\
\hline 6 & $\begin{array}{l}\text { As part of the top management in our firm (SBU), I } \\
\text { monitor the diffusion of proprietary knowledge out- } \\
\text { side the organization in order to ensure that the goals } \\
\text { of the firm (SBU) are achieved. }\end{array}$ & 1 & 2 & 3 & 4 & 5 \\
\hline $\begin{array}{l}\text { As part of the top management in our firm (SBU), } \\
\text { I monitor scale effects (product depth) in order to } \\
\text { ensure that the goals of the firm (SBU) are achieved. }\end{array}$ & 1 & 2 & 3 & 4 & 5 \\
\hline $\begin{array}{l}\text { As part of the top management in our firm (SBU), } \\
\text { I monitor scope effects (product depth) in order to } \\
\text { ensure that the goals of the firm (SBU) are achieved. }\end{array}$ & 1 & 2 & 3 & 4 & 5 \\
\hline
\end{tabular}


Gadjah Mada International Journal of Business - September-December, Vol. 23, No. 3, 2021

\begin{tabular}{|c|c|c|c|c|c|c|}
\hline No. & Statements & SD & $\mathbf{D}$ & $\mathbf{N}$ & A & SA \\
\hline 9 & $\begin{array}{l}\text { As part of the top management in our firm (SBU), I } \\
\text { monitor input costs in order to ensure that the goals } \\
\text { of the firm (SBU) are achieved. }\end{array}$ & 1 & 2 & 3 & 4 & 5 \\
\hline 10 & $\begin{array}{l}\text { As part of the top management in our firm (SBU), } \\
\text { I monitor internal product innovations in order to } \\
\text { ensure that the goals of the firm (SBU) are achieved. }\end{array}$ & 1 & 2 & 3 & 4 & 5 \\
\hline \multirow[t]{2}{*}{11} & $\begin{array}{l}\text { As part of the top management in our firm (SBU), } \\
\text { I monitor factors that affect customer's purchasing } \\
\text { power. }\end{array}$ & 1 & 2 & 3 & 4 & 5 \\
\hline & Strategic Risks & & & & & \\
\hline 1 & $\begin{array}{l}\text { The safety of our operations is critical to achieving } \\
\text { our firm's (SBU's) strategy. }\end{array}$ & 1 & 2 & 3 & 4 & 5 \\
\hline 2 & $\begin{array}{l}\text { The quality of our operations is critical to achieving } \\
\text { our firm's (SBU's) strategy. }\end{array}$ & 1 & 2 & 3 & 4 & 5 \\
\hline 3 & $\begin{array}{l}\text { The reliability of our operations is critical to achiev- } \\
\text { ing our firm's (SBU's) strategy. }\end{array}$ & 1 & 2 & 3 & 4 & 5 \\
\hline 4 & $\begin{array}{l}\text { The efficiency of our operations is critical to achiev- } \\
\text { ing our firm's (SBU's) strategy. }\end{array}$ & 1 & 2 & 3 & 4 & 5 \\
\hline 5 & Firms (SBUs) enter our industry easily. & 1 & 2 & 3 & 4 & 5 \\
\hline 6 & $\begin{array}{l}\text { It is difficult for a customer to leave our firm (SBU) } \\
\text { and begin a relationship with a new firm (SBU) in our } \\
\text { industry. }\end{array}$ & 1 & 2 & 3 & 4 & 5 \\
\hline 7 & $\begin{array}{l}\text { Our competition is fragmented (i.e. fragmented is } \\
\text { one in which many firms (SBUs) hold small relative } \\
\text { market shares). }\end{array}$ & 1 & 2 & 3 & 4 & 5 \\
\hline 8 & $\begin{array}{l}\text { It is difficult for our firm (SBU) to leave one supplier } \\
\text { and begin a relationship with another supplier. }\end{array}$ & 1 & 2 & 3 & 4 & 5 \\
\hline \multirow[t]{2}{*}{9} & $\begin{array}{l}\text { Our firm (SBU) is concerned about the threat of } \\
\text { substitute products. }\end{array}$ & 1 & 2 & 3 & 4 & 5 \\
\hline & Managerial Performance & & & & & \\
\hline 1 & $\begin{array}{l}\text { Financial performance has met the firm's or prof- } \\
\text { it-center SBU's target. }\end{array}$ & 1 & 2 & 3 & 4 & 5 \\
\hline 2 & $\begin{array}{l}\text { Sales growth of product/service markets has met the } \\
\text { firm's or profit-center SBU's target. }\end{array}$ & 1 & 2 & 3 & 4 & 5 \\
\hline 3 & $\begin{array}{l}\text { Relative market share for products/services has met } \\
\text { the firm's or profit-center SBU's target. }\end{array}$ & 1 & 2 & 3 & 4 & 5 \\
\hline 4 & $\begin{array}{l}\text { Overall performance has met the firm's or profit-cen- } \\
\text { ter SBU's target. }\end{array}$ & 1 & 2 & 3 & 4 & 5 \\
\hline
\end{tabular}




\section{SURVEY QUESTIONS SECTION C}

For each question below, please choose the best response.

1. What is the size of your firm or profit-center SBU?

a. Micro (maximum total value of assets other than land and buildings is Rp 50 million, or maximum annual sales are Rp 300 million, whichever is higher)

b. Small (maximum total value of assets other than land and buildings is between Rp 50 million and $\mathrm{Rp} 500$ million, or maximum annual sales are between $\mathrm{Rp} 300$ million and Rp 2.5 billion, whichever is higher)

c. Medium (maximum total value of assets other than land and buildings is between $\mathrm{Rp} 500$ million and $\mathrm{Rp} 10$ billion, or maximum annual sales are between $\mathrm{Rp} 2.5$ billion and $\mathrm{Rp}$ 50 billion, whichever is higher)

d. Large (total value of assets or annual sales is above those of the medium category, whichever is higher)

2. Is your firm publicly listed on the Indonesia Stock Exchange (IDX)?
a. Yes
b. No

3. Please specify the industry sector of your firm or profit-center SBU.
a. Financial - Banking
b. Financial - Other Financial Services
c. Mining
d. Manufacturing
e. Agricultural
f. Fishery
g. Trading (Domestic \& International)
h. Other ...... 